\title{
日本における近代日本文学研究の現状と課題
}

日比嘉高

$凶$ hibi@nagoya-u.jp

This paper reports current trends and issues in modern Japanese literary studies in Japan. First, I discuss the state of universities in Japan amid the current governmental initiative to "reform universities," addressing the functional differentiation of national universities and the pressures of globalization. Next, I touch on changes in research conditions and the state of publishing, noting an increase in the number of publications based on Ph.D. dissertations by younger researchers and advancements in the digitization of research materials. After addressing current political circumstances that are influencing these matters, I discuss changes in the type of graduate students conducting studies on Japanese literature, new academic trends in modern Japanese literary studies, and insights from the analysis of the JSPS grants (Kakenhi) database.

\footnotetext{
Keywords modern Japanese literature(近代日本文学), literary study(文学研究), publication(出版), Grants-in-Aid for Scientific Research(科研費), agendas (課題)
} 


\section{1. 日本の大学を取り囲む現状——大学改革」}

本論では「日本における近代日本文学研究の現状と課題」という大きな課題で報告を行 う。はじめに日本の大学を取り囲む現状、とりわけ「大学改革」についての概観を提示 し、次に研究環境および出版状況の変化について私見を述べる。関連する政治的状況に ついて指摘を行った後、日本文学研究に関わる大学院生についての変化、そして日本に おける近現代文学研究の最近の動向、科研費データベースから見る最近の動向について 短くまとめた。なお本論の元になった報告は2015年5月に行われたものであり、情報の 更新は部分的にしか行っていないことを申し添える。

現在、日本の大学、とりわけ国立大学は大きく摇れている。安倍晋三首相が主導して 描いている日本の成長戦略のなかに「大学改革」が含まれており、それを受けて文部科学 省が競争主義的な施策や要請を次々と繰り出しているからである。

国立大学については、その役割をタイプ別に分化し「機能強化」するという方針が打 ち出されている。具体的には、卓越した成果を出す海外大学と伍して全学的に取り組む タイプの大学、主地域の課題に応じ貢献するタイプの大学、特色のある分野で世界的. 全国的な教育研究を行うタイプの大学という三つのタイプに国立大学は分類され、実際 この方針のもと、大学は予算の傾斜配分を受けている゙。学は自らの存在の理由を方向 付けられ、そして方向付けられた大学は、自身の大学構成員にも同じ方向を向くよう、 あからさまに、あるいは暗黙のうちに要請することになる。

さらに問題なのは、現政権が主導する「大学改革」が経済的な観点を基調にしていると いうことである。安倍首相は、2014年5月6日にパリで開かれた OECD (経済協力開発機 構)閣僚理事会の基調演説で、日本への投資を呼びかけながら次のように述べた。「私 は、教育改革を進めています。学術研究を深めるのではなく、もっと社会のニーズを見 据えた、もっと実践的な、職業教育を行う。そうした新たな枠組みを、高等教育に取り 込みたいと考えています」。

経済的観点から「大学改革」が進められようとしていることを、より端的に表してい るのは、議論が「産業力競争会議」によって主導されているという事実である。この会議 は内閣府に設けられた日本経済再生本部のもとに置かれた会議で、下位のワーキンググ ループに新陳代謝・イノベーション部門があり、ここがいま大学改革を論じているので ある。

この現政権の方向性は、日本の人文社会科学そして教育学のあり方に深刻な脅威とな りつつある。2014年の夏、「国立大学法人の組織及び業務全般の見直しに関する視点」 について(案)」(2014年8月4日付)という国立大学法人評価委員会の文書が話題となった。 そこには次のように書かれていたのである。

1「平成28年度における国立大学法人運営費交付金の重点支援の評価結果について」文部科学省、2016年3月9日。 
「ミッションの再定義」を踏まえた速やかな組織改革が必要ではないか。特に教員 養成系学部·大学院、人文社会科学系学部. 大学院については、18歳人口の減少や人材 需要、教育研究水準の確保、国立大学としての役割等を踏まえた組織見直し計画を策 定し、組織の廃止や社会的要請の高い分野への転換に積極的に取り組むべきではな いか。

教員養成系、人文社会学系の学部大学院は不要であると言っているようにしか読めな いこの文書は、大学教員とりわけ文系の教員たちに驚きと怒りをもって迎えられた。批 判の声が巻き起こり、私自身もブログの記事やメディアの関連記事への協力、著作の刊 行などで問題点を指摘してきた。だが残念ながら「改革」の嵐は収まるようすはない。

現在、多くの国立大学で新学部・新研究科の設立が始まっている。その形態はさまざ まだが上記の三分類に沿わせつつ、人文社会系と教員養成系の既存組織の規模縮小や転 換が進行中である。人文社会系学部・大学院にもその影響は当然及びつつあるが、より 深刻なダメージを受けているのは教員養成系学部・大学院である。日本の教員養成系学 部・大学院には多くの日本文学研究者が所属している。「国語」の教員養成のために、「教 科専門」などと呼ばれる分野を担当するのである。つまり、教員としての高度な知識を 身につけるために、文学研究や日本語学、漢文学などの専門研究者が配置されているの である。これらの教科専門の研究者が、いま立場が危うくなりつつある。教員養成系大 学・大学院は、より「実践的」な教育を行うことが必要で、高度な専門的知識は必要ない というのが、教育学部「改革」を進める勢力の基本的な発想であるらしい。

もう一つ、盛んに唱えられているのが大学の「グローバル化」である。タイムス・八 イヤー・エデュケーション(THE)などをはじめとする大学ランキングが話題に上り、外 国人教員や留学生数の増加が目指されている。英語による講義の数を増やすということ も、目標の一つである。私の所属校にも、ほとんどの学部／研究科に英語コースが作ら れた。文学部にも「アジアの中の日本文化」コースというのができている。のちに改め てふれようと思うがグローバル化そのものは、学術にとって悪いことではないと私は 思っている。ただし、それが健全なかたちでなされる限りにおいては。

\section{2. 研究環境と出版状況の変化}

次は、文学研究に絞った変化について概観を試みる。まず、2000年代以降の傾向と して定着したのは、大学院生の博士論文が出版されるという道筋である。以前は、単著 の研究図書の刊行は、かなり経験を積んだ年長者の行うことだというイメージが強かっ たと聞く。それが2000年代に入ってから、大学院を出てすぐぐらいの若手が本を出すと いう状況へと変化した。背景には博士号取得者の増加と、就職難がある。ほぼ同じぐら いの時期から、課程博士号を積極的に与える大学院が増え、博士号取得者が増えた。 
ちょうど日本の第二次べビー・ブーマーが大学に職を求める時期と重なり、研究職に就 くことが非常に難しくなった。博士号を取得しても決定的な業績にならないことがわか ると、次は博士論文を出版することによって競争を勝ち抜こうとする状況に至ったわけ である。

研究環境で言えば、デジタル化がようやく進みつつある。国立国会図書館デジタル コレクションは公開点数をどんどんと増やしているし、2014年には、「館内限定」とさ れていた資料を連携図書館において見ることができるサービスも始めた。一般公開され ているデジタルコレクションは、著作権が切れた資料だけが対象である。だが国会図書 館がデジタル化している資料は、著作権保護期間中のものも含めた膨大な数に上ってい る。これらは「館内限定」での閲覧——つまり実際の訪問と同じ扱い——で閲覧に供され てきたが、これが他の地域の図書館でも見られるようになったのである。これは非常 にありがたい変化であった(ただし提携館の数はまだまだ少ない)。国会図書館は「国会 図書館サーチ」という統合検索サービスも始めており、図書の検索だけでなく、雑誌記 事の検索、他の公共図書館の蔵書検索など複数のサービスを横断的に調べられるように なっている。

『朝日新聞』や『読売新聞』『毎日新聞』な゙の大手新聞も、ほぼデジタル化を完了してい る。契約した図書館等でなければ見ることはできないが、見出しや、場合によっては本 文の検索もできるようになっており、有用である。

各大学がリポジトリとよぶ、自分たちの大学に関連した研究成果を電子公開する流れ も加速している。背景には、電子ジャーナルの高騰という世界的な問題も存在する。無 料で研究成果にアクセスできる状態を提供するための基盤整備である。これが進み、ま だまだ数は少ないが、検索結果に表れた論文をそのままパソコンで読める場合も増えて 来た。

研究資金の性格の変化も、研究のあり方に影を落としているように思う。現在、ど この大学でも、無条件に与えられる研究費の額が大きく減っており、そのかわりに科研 費をはじめとする外部資金を獲得してくるように求められている。外部資金は、研究計 画を立案し、場合によっては研究チームを結成し、そして短期的な成果が求められる。 これが研究を活性化している面はたしかにあるが、より資金を獲得しやすいテーマが選 ばれがちになることは否めない。時間のかかるテーマ、関心を引きにくいテーマに は、研究資金も研究時間も割きにくい構造になっている。

外部資金の増加が複数の研究者によるチーム研究を増加させていることは今述べた が、この傾向が外国の研究者との連携を増やす効果を生んでいる。とりわけ、満洲や上 海、朝鮮半島、台湾など旧植民地、日本人居留地の研究においては、中国、韓国、台湾 などの研究者と共同研究を行う機会が増えている。

なお、どのような研究計画が科研費を獲得しているのかについては、最後にあらた めて検討する。 


\section{3. 現在の政治的状況}

ここで、現在の日本の政権の政治的傾向およびそれに呼応する排外主義的な一部の市 民の傾向と、日本文学研究の状況について触れておく。安倍晋三首相率いる現在の政権 が、視野の狭い自国愛にとりつかれており、教育、軍備、歴史認識などにおいて戦後日 本の枠組みを大きく修正しようとしていることは、海外のメディアでも伝えられてい るところだろう。この政権のもと、文部科学省は学校教育において日本文化を教えるこ とを重視し、愛国心を強めよう、日本人としてのアイデンティティを強化しようという 方向を打ち出している。海外においても、ジャパン・八ウスという日本文化についての 広報施設の設置や、アメリカの著名大学の日本学講座に対する財政支援など、日本文化 の海外発信にも熱心である。

大学も無縁ではない。2015年には文部科学省が大学に対し、入学式や卒業式で国旗を 掲揚し、国歌を歌わせるよう「要請」する方針を示した。従った大学も、従わなかった大 学もあり、対応は分かれた。

首相官邸に設置された教育再生実行会議による「これからの大学教育等の在り方につ いて(第三次提言)」(2013年5月28日)という文書には、大学をグローバル化するための提 言が含まれているが、そのなかに「日本人としてのアイデンティティを高め、日本文化 を世界に発信する」という条項がある。こうした素朴な愛国心が、そのまま高等教育に ついての政府目標になってしまうことについては、悲しみを通り越して滑稽さすら感 じる。

一部の歴史修正主義的な新聞と、それに呼応する政治思想を持った市民(団体)が、大 学で行われている講義に直接的に介入を始めていることも、最近の大きな特徵である。 2014年には従軍慰安婦についてのドキュメンタリーを上映した、ある大学の授業が攻撃 を受けた。授業の受講生が新聞に投書し、それが大きく取り上げられた。これを受け て、大学に抗議の電話が多くかけられ、政治思想を同じくする国会議員が文部科学省に 見解を求めるということも起こった。

日本文学に関連する授業が、こうした攻撃の対象になったという話は今のところ聞 いていない。むしろ、「日本文化」の関心を高めようという政権の方針からすれば、日 本文学についての教育研究は、親和的でさえありうる。だが火種はくすぶっていると考 えておいた方がいいだろう。「反日的」とみなされる授業や言動を行ったとき、いつど こで攻撃の火の手が上がってもおかしくないと、私自身は感じている。日本国内で生活 する東アジア出身の留学生や教員は、より敏感に、危険の中にいることを感じているは ずである。 


\section{4. 大学院生に関する変化}

1990年代と比べて大学院生の数は日本文学分野全体として減少している。とりわ け、古典文学研究ではこの傾向は顕著で、学会の高齢化が進行しているとも聞き及ぶ。 近代文学研究でも同様だが、近年の院生数のピークは、1970年代前半生まれの第二次べ ビー・ブーマーたちが院生だった時代にあったが、その後は人口減が続いており、その まま院生数の減少に結びついている。さらに景気の悪化が重なり、大学における日本文 学系講座やポストの縮小傾向も追い打ちを掛け、まず古典分野の教員の削減が先行し た。当然ここれは院生たちにとって深刻な就職難をもたらした。大学院の入学志願者が 減るのは、当然である。

そしてこの院生数、正確に言うと日本人院生数の減少を、留学生の大学院生たちが補 填しているという現象がある。大学によって比率の違いはあるが、相対的に学費の安い 国立大学大学院の日本文学系講座においては、現在約半分ほどが留学生となっているは ずである。

出身国にも変化がある。私が大学院生時代を送った1990年代後半においては、留学生 の多数派は韓国人だった。現在はほとんどの大学で、九割方を中国大陸からの留学生が 占めているのではないか。余談だが、韓国人留学生は終了後に帰国する割合が高いが、 中国大陸からの留学生は修士課程修了後に、日本の企業に就職することも珍しくない。 大学のみならず、日本の社会にとっても大きな変化である。

海外で日本文学を教えている大学教員からしばしば聞くのは、日本文学を専攻する学 生たちの「入り口」がマンガやアニメなどのポップカルチャーとなっているという話で ある。私の講座に入学する留学生たちは表だってそれを言わないが、親しくなってから 聞いてみれば、マンガやテレビアニメ、アイドルグループなどのファンである(あっ た)ことがしばしばである。この変化をどう考えればよいかは、まだよくわからない。 ただ、日本における日本近代文化研究が、ポップカルチャーの研究をうまく進められて いない一一部の文学研究者、社会学者、映画研究者などが扱ってはいるが、ただし大 学のポストはわずかである—ことはたしかである。その意味では、潜在的な需要を救 い損ねており、社会に向かって発するべきこの分野についてのアカデミックな知見を産 出できていない状態にある。ただし、学生の興味関心や授業の受容と、学界の興味関 心、そして大学のポストとが必ずしも一致しないのは、どこの国でも同じであろう。

\section{5. 日本における近現代文学研究の最近の動向}

近年の近現代文学研究の対象領域としては、どのような動向がみられるのか、まず は個人的な観察をもとに概観してみる。「戦後50年」の節目以降の傾向だが、戦後につい ての研究は厚みを増している。とりわけプランゲ文庫の資料を用いたGHQ占領期の検閲 
研究は目覚ましい進展を見せた。ジャーナリズム研究者の山本武利が牽引したプランゲ 文庫のデータベース化と分析が特筆されるべきだが、岩波書店の『占領期雑誌資料大系』 (2008-10年)も刊行されている。近代文学研究者でも横手一彦、十重田裕一、川崎賢子、 天野知幸らが考察を発表している2。

戦後文化の研究も進んでおり、サークル運動などについては不二出版の『戦後文化運 動雑誌叢書』など雑誌復刻もあって関心が集まっている。充実した宇野田尚哉·道場親信 ほか編『サークルの時代」を読む——戦後文化運動研究への招待』(影書房、2016年)が刊 行されており、中村不二夫、水溜真由美、鳥羽耕史、坪井秀人らにも論考がある ${ }^{3}$ 。高度 経済成長期についても石川巧の『高度経済成長期の文学』が出た。

ライトノベルについても、研究の蓄積が増えた。一柳廣孝と久米依子の編集による 二つの論文集があり、大橋崇行と山中智省が編者を務めたシリーズ『ライトノベル・フロ ントライン』 3 巻もある5

研究会としては2014年に十九世紀文学研究会(発起人・山田俊治、谷川惠一、高木元、 中丸宣明)が発足したことが注目される。学会形式ではなく、会員制度も取っていない という。故・花田俊典の呼びかけで始まり、長野秀樹や川口隆行らが運営に関わる原爆 文学研究会も熱心で質の高い研究を続けている。この他活発な個人作家研究会・学会とし て、横光利一文学会、有島武郎研究会、宮沢賢治研究会、国際芥川龍之介学会がある。谷 崎潤一郎研究会は、残念ながら最近休止となった。

その他、任意に上げていけば、谷崎潤一郎の新全集が刊行され、新資料も続々と発見 (公表)されている。戦争の記憶や、あるいは戦場を描く文学にも関心が高まっていると 感じる。2015年は「戦後70年」の節目となっているということもあ万うが、むしろ日本 社会に「戦前」の色が濃くなっているといら不安が関係しているのではないか。さほど活 発に研究が進められているわけではないが、西田谷洋が先鞭を付けた認知物語論につい ても新しい課題として注目しておくべきだろう。私自身も発表をしたり論考を書いたり したが、若い研究者から質問をしばしば受け、潜在的な関心が広がっていると感じた。 最後に東アジアと同時代日本語文学フォーラムおよびその機関誌『跨境 日本語文学研究』

\footnotetext{
2 代表的なもののみを挙げる。以下同。横手一彦『被占領下の文学に関する基礎的研究 資料編』(武蔵野書房, 1995 年)。十重田裕一「交錯する二つの検閲の痕跡——占領期日本の文学テクスト再検討の視点」(『昭和文学研究』 62，2011年）。川崎賢子「GHQ検閲と「古典」評価の变容(特集プランゲ文庫研究の10年)」(『Intelligence』12, 2012 年)。天野知幸「「満洲文学」のゆくえ- GHQ/SCAP検閲と地方雑誌の調査を踏まえた考察」( 京都教育大学国 文学会誌』39,2013年)。

3 中村不二夫『戦後サークル詩の系譜—中村不二夫詩論集』(ナカニシヤ出版, 2013年)。水溜真由美『サークル 村』と森崎和江一一交流と連帯のヴィジョン』(ナカニシヤ出版, 2013年)。鳥羽耕史「文壇とその外部一一九 五○年代のサークル詩集、生活記録集の編集をめぐって」(『文学』17(3)，2016年)。坪井秀人「サークル運動評 価の困難さ」(『社会文学』33,2011年)。

4 石川巧『高度経済成長期の文学』(ひつじ書房, 2012年)。

5 一柳廣孝·久米依子編『ライトノベル研究序説』(青弓社, 2009年)。一柳廣孝·久米依子編著『ライトノベル・スタ ディーズ』(青弓社, 2013年)。大橋崇行·山中智省編著『ライトノベル・フロントライン』 1 (青弓社, 2015-2016年)。 なお大橋には単著『ライトノベルから見た少女／少年小説史——現代日本の物語文化を見直すために』笠間 書院, 2014)もある。
} 
についても、関心が寄せられていることをつけ加えよう。東アジアの複数地域との研究 連関といら形を取りつつ、年刊の査読誌を発行したことは日本文学研究の新しい時代を 切り開くものとして評価されている。

\section{6. 科研費データベースから見る最近の動向}

以上は私見による整理だが、より客観的なデータも利用してみよう。現在、日本で 大学などに所属して研究を行う研究者のもっとも重要な外部的(つまり勤務校以外の)研 究資金源となっている科学研究費補助金の、データベース「科学研究費助成事業データ ベース」を利用する。

グラフ1は1972年から2017年までの、「国文学／日本文学」分野の採択件数のグラフで ある。増減の波はあるが、基本的には大きく増加していることが分かる。背景には、所 属校の研究予算が減らされ、外部の競争的資金を得ようとする研究者が増えていること がある。グラフ2は全分野の採択件数のうちに「国文学/日本文学」が占める割合のグラ フである。1980年代から 90年代にかけて落ち込みがみられるが、その後は上昇してい る。とはいっても、0.17\% 0.45\%の範囲内での増減であり、さほど有意とは言えない かもしれない。ただ、全体の採択件数が減る時には、占有割合も低下しているようには 見える。つまり、減額の影響を受けやすい分野だとは言えそうだ。

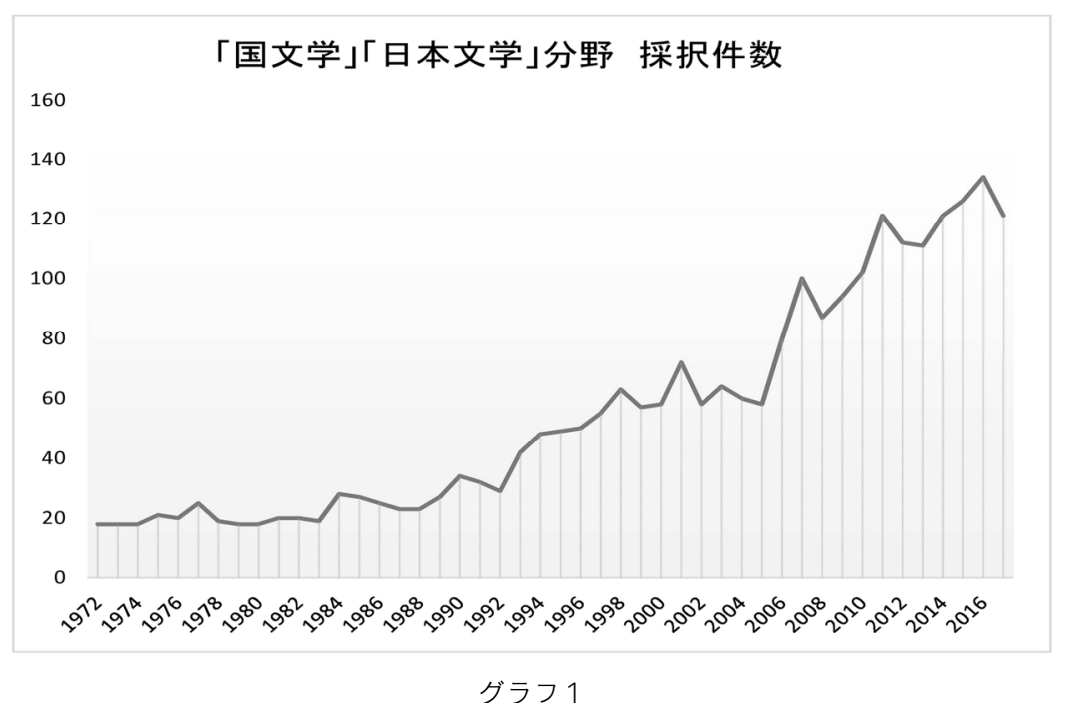




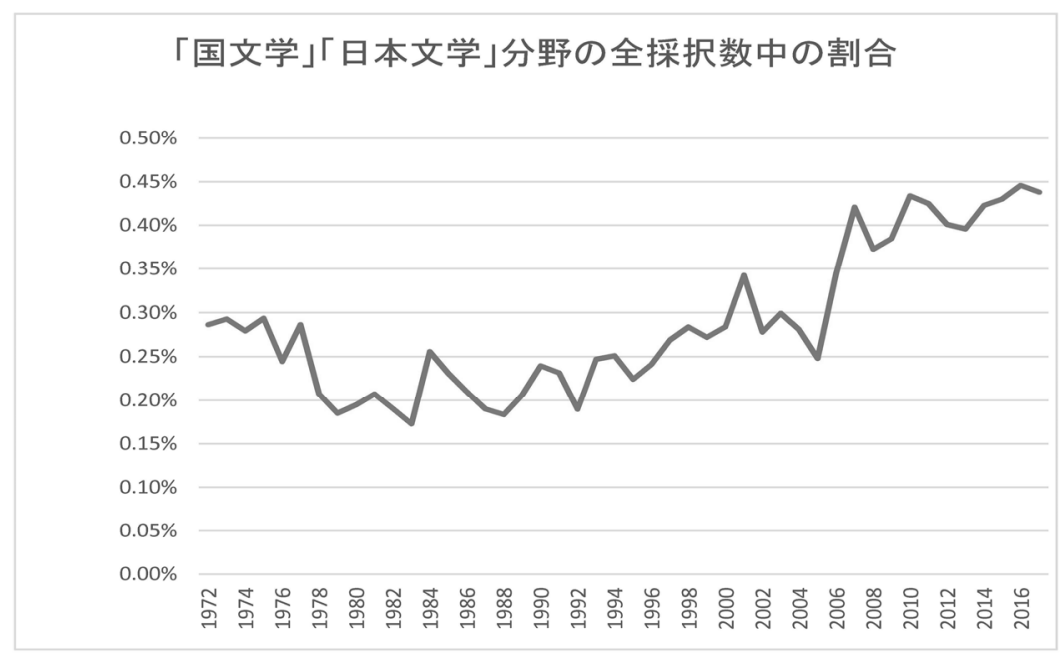

グラフ 2

表 1 には、2013年から2017年まで5年間の近現代文学・文化にかかわるすべての採択 課題のタイトルを示した。手元の集計では合計240件である。日本文学分野全体は613件 なので、近現代文学で $39.1 \%$ となる。

全体を見渡した特徵は、分散的だということである。こうした報告で述べることと してはインパクトがないようだが、つまり、いろいろな研究が幅広くなされていると いうことである。「面白くない指摘」だが、しかし研究分野全体の健全さを示すものとし て、歓迎すべきことだと私は捉えた。ただし、研究の中心はあきらかに戦後すなわち 1945年以降の文学・文化に移りつつある。戦前期の研究も依然多いが、20年前と比べれ ばその遷移は明瞭だろう。

全体として分散的だとはいえ、いくつか重なりが観察される関心領域がないわけでは ない。一つは、先にも述べた GHQの占領および検閲に関わる研究である。またメディ アへの注目も従来から引き続いていることが確認できる。近年の傾向として、一つのメ ディアに注目するだけでなく、メディア・ミックスを分析の軸とする課題が増えている と言えるかもしれない。よくある論の構えではあるが、受容研究や、前時代との接続を 考察するような課題も依然として人気がある。この変形と言えば言えるが、美術や映画 など隣接領域との交渉も課題として選ばれやすい。地域性に目を向けると、欧米よりも アジアとの関係に着眼する研究が多い。中国大陸に着目する研究が増えつつあり、南米 を題材とする研究が現れるようになった。外部資金調達という目的に合致しやすいため かもしれないが、資料調査およびそのデジタル化は、さまざまな所蔵先や作家につい て進められていることが確認できる。その他、障害者やハンセン病について注目する視 点もある。探偵小説・推理小説も比較的関心を集めているテーマのようである。

科研費の採択課題は、大学などに所属する研究者と、日本学術振興会の特別研究員に 
採用された若手研究者の申請をもとにしている。一応、全世代の研究者をカバーする データだとは言えるが、もっとも厚い層は、30 50歳代の研究者だろう。また、短期間 で成果を求められる学外の競争的資金であることから、より獲得しやすい課題に誘導さ れるという傾向がある。したがって、実際には遂行されているが、評価を得にくい課題 （たとえば現代文学や「正典的すぎる」作家など）であったり、長期的な課題であったりす るものは、ここに現れにくい仕組みとなっている。

今回は分析できなかったが、『日本近代文学』や『日本文学』『昭和文学研究』といった全 国レベルの学会誌に掲載された論文の傾向を分析したり、国会図書館のNDL-OPACを利 用したりして博士論文の傾向を調べることもできるだろう。現在の博士課程の学生たち が、どのようなテーマを選んでいるのかが、そこから見えてくるに違いない。

\section{7. 近現代文学研究のこれからの課題}

最後に、日本の近現代文学研究が取り組むべき課題について、簡単に私見を述べて結 びとしよう。研究が手薄な領域としては、1970年代以降の文学がある。とりわけ、文学 史としてはまだ広く共有される枠組みが提示されていない。戦後の大衆文学についても 関心の濃淡が大きい。戦後の文芸メディアの研究についても、きちんとした整理はされ ていない。

日本以外の地域で行われている日本文学研究の成果を、日本語を用いて日本で研究し ている研究者たちに、どのようにしてより容易にアクセスできるようにするかという のも、重要だが難しい課題だ。同様に、日本で行われている研究も、より広く海外の研 究者たちに読まれるためにはなにをすれば良いのかも、考えた方がよいだろう。日本 語の論文を組織的に英訳して刊行する一一たとえば雑誌ごと一一などということも検討 してもよいのではないか。

日本国内の大学で教鞭を執る外国人の日本文学研究者の数も、もっと増やすべきだろ う。現在の留学生の比率からすれば、そうなって当然である。外国人研究者が増えれ ば、自然と、学界の関心や手法、形態も新しい展開を迎えるだろうし、学部大学院への 学生の集まり方も変わってくるだろう。 
表1：近現代文学・文化にかかわる科研費採択課題タイトル 2013-2017

\begin{tabular}{|c|c|c|}
\hline 開始年度 & $\begin{array}{c}\text { 研究課題／ } \\
\text { 領域番号 }\end{array}$ & 研究課題名 \\
\hline \multirow[t]{44}{*}{2013} & 25884067 & |日本近代文学における座談会の文学·批評的意義 \\
\hline & 25870285 & 戦後アヴァンギャルド芸術によるジャンルと国境の横断－安部公房を事例に \\
\hline & 25870079 & 1960年代の文学と視覚メディアの交錯についての文体論的研究 \\
\hline & 25770095 & 1920-30年代における「文学の価值化」と「価値哲学」の理論的関係の研究 \\
\hline & 25770094 & 井伏鱒二作品における地方表象の研究一1930-50年代を中心に \\
\hline & 25770091 & 日本近代文学におけるく文学賞>の意義と作用—『改造』懸賞創作を中心に \\
\hline & 25770090 & 1930 40年代の朝鮮、台湾、満洲における日本語文学と“言説の磁場”の検討 \\
\hline & 25770088 & <近代説話 $>$ 研究 - 明治大正期の実録、実記、講談本から歴史小説、大衆文学へ - \\
\hline & 25770086 & 1920 30年代の大衆文学の展開とメディア.ミックス現象に関する総合的研究 \\
\hline & 25770084 & 1960年代のテレビ文化黎明期におけるテレビドラマ制作と<文学 $>$ \\
\hline & 25770083 & 「営業案内」「職業案内」に関する出版史料的価値の検討 \\
\hline & 25770080 & 江戸川乱歩旧蔵書の書誌調査 \\
\hline & 25770076 & 夏目漱石初期·中期作品における表現の視覚性 \\
\hline & 25770073 & 1920年代の日本モダニズム文学における「東洋」「「伝統」言説の形成 \\
\hline & 25704006 & 知的障害者表象に関する比較文学研究とデータベースの構築 \\
\hline & 25580058 & 忍者と探偵、近代日本におけるキャラクター表象の形成と海外伝播に関する文化研究 \\
\hline & 25580057 & 近代日本の人文知形成に関する基礎研究—『郵便報知新聞』掲載外国小説原典調査から \\
\hline & 25580055 & 戦時下文学史の再編成に向けて－階層性とジェンダーの観点から一 \\
\hline & 25580054 & 「世界戦略」としての三島由紀夫 \\
\hline & 25370255 & 文化政治前期の植民地朝鮮における図書館とく翻訳〉一日韓文化交流史の再構築一 \\
\hline & 25370253 & 『長崎そのときの被爆少女』成立過程確定を軸とした長崎原爆文学に関する基盤的研究 \\
\hline & 25370251 & 日本統治下上海を中心とした中支各地域における日本語文学状況の基礎的研究 \\
\hline & 25370249 & 全集未収資料集の作成による藤村研究の再構築 \\
\hline & 25370246 & 大岡昇平文学の基礎的および総合的研究一創作ノート・原稿類を含む一 \\
\hline & 25370242 & 日本近代文学館他における川端康成·肉筆資料の調査研究 \\
\hline & 25370240 & 1950-60年代日本文学の英語訳に関する基礎的研究 \\
\hline & 25370239 & 「歴史·時代小説ブーム」の戦後精神史 (二大作家の比較研究による) \\
\hline & 25370238 & 宮沢賢治の草稿生成論的研究一『風の又三郎』を中心に一- \\
\hline & 25370233 & 林芙美子文学から見る近現代アジア諸国の研究 \\
\hline & 25370228 & 森家所蔵森敦自筆資料による基礎的研究 \\
\hline & 25370227 & 倉敷市蔵「薄田泣董文庫」の調査及び関連書誌の作成と分析 \\
\hline & 25370225 & 夏目漱石の文芸と美術との相関一漱石文庫資料による実証的研究 \\
\hline & 25370223 & 松代·一関·南部·秋田各藩の和歌活動·俳諧活動による大名文化圈形成解明の新研究 \\
\hline & 25370222 & 博覧会の時代と泉鏡花 \\
\hline & 25370221 & 本地垂迹の視点から見た慈円法楽歌についての基礎的考察 \\
\hline & 25370220 & 戦後沖縄文学に関する思想史的研究 \\
\hline & 25370217 & 分析書誌学と出版史的方法による近代日本における書物の制度化の解明 \\
\hline & 25370215 & 全国書房ネットワークの総合的研究一戦時下 占領期における文学と出版メディア一 \\
\hline & 25370213 & 幕末から明治初期の岐阜の芝居(劇場と役者)の実態 \\
\hline & 25370208 & 明治期の<知 >とメディア言説を通してみた軍記文学の文化的展開に関する基礎的研究 \\
\hline & 25370207 & 近世近代の枠を越えた十九世紀絵入小説史を記述するための書誌学的研究 \\
\hline & 25370205 & 占領期ローカルメディアに見る文学者·出版関係者のネットワーク形成に関する研究 \\
\hline & 25370204 & 1960年代 70年代の日本の放送メディアにおける寺山修司の創作活動の研究 \\
\hline & 25370202 & 森鴎外の訳業を媒体とした1910年代日欧文化情報伝達の調査と分析 \\
\hline
\end{tabular}




\begin{tabular}{|c|c|c|}
\hline 開始年度 & $\begin{array}{c}\text { 研究課題／ } \\
\text { 領域番号 }\end{array}$ & 研究課題名 \\
\hline & 25284052 & 中日文化協会上海分会と関連文学者·文化人に関する基礎的·総合的研究 \\
\hline \multirow[t]{44}{*}{2014} & 26884076 & 明治期の西鶴流行現象における内田不知庵の西鶴評価と翻刻出版に関する総合的研究 \\
\hline & 26884052 & 台本を基礎資料とする明治期歌舞伎の作品研究 \\
\hline & 26870514 & 現代文学における「地域」と「開発」をめぐる系譜学的研究 \\
\hline & 26870132 & 近現代日本における古典文学の受容と関連文化財の評価の連動性 \\
\hline & 26870069 & 明治後期の日本外地における漢詩文活動とその思想の実証的研究——籾山衣洲を中心に \\
\hline & 26770094 & 1920-50年代の東アジア／日本の言論インフラをめぐる総合的研究 \\
\hline & 26770092 & 日本近代文学における翻訳と創作の創造的連関 \\
\hline & 26770091 & 日満文学者の交流に関する総合的調査と研究一川端康成の旧満州紀行を一事例として一 \\
\hline & 26770089 & 〈戦後〉雑誌における文学者の美術批評に関する基礎的研究 \\
\hline & 26770087 & 〈旧訳 >を中心とした谷崎源氏テクストに関する基礎的研究一翻訳文学としての再検討一 \\
\hline & 26770086 & 佐藤春夫旧蔵資料による文壇ネットワークの解析 \\
\hline & 26770085 & 未活字化の日記資料群からみる近代日本の青年知識層における自己形成の研究 \\
\hline & 26770083 & 戦時体制下における雑誌メディアの書誌的研究 \\
\hline & 26770080 & 出版メディアを基盤とした江戸板浮世草子·俳諧及び作者の総合的研究 \\
\hline & 26770078 & 終戦直後の新聞小説の研究一織田作之助を中心に \\
\hline & 26580048 & 日本近代文学における活字文化と美術との共鳴に関する研究 \\
\hline & 26580047 & 欧米並びにアジアとの比較を介した日本近代文学及び映画における死の表象の再構築 \\
\hline & 26370264 & 戦後日本文学の再「転向」一舟橋家所蔵資料による大衆文学の新視点 \\
\hline & 26370263 & 夏目漱石によるイギリス受容一小説理論の構築の一環として \\
\hline & 26370262 & 言文一致運動と近代における短歌表現の研究 \\
\hline & 26370261 & 地方における文芸コミュニティの形成と変容に関する研究一暮鳥会寄託資料を軸として \\
\hline & 26370260 & 朝鮮総督府発行教科書·教授書·編纂趣意書に見られる「同化思想」の形成について \\
\hline & 26370258 & 折口信夫旧蔵資料の調査とその評価を通じた同時代文学の資料学的研究 \\
\hline & 26370254 & GHQ占領期における近代化及び古典再編に関する諸言説分析を総合する文芸史的研究 \\
\hline & 26370253 & 明治·大正期文学の中産階級読者から見た「女の謎」表象に関する総合的研究 \\
\hline & 26370250 & 中南米日系移民および韓国系移民による文学に関する総合的研究 \\
\hline & 26370249 & 文学雑誌『若草』における読者階層の形成と混交をめぐる総合的研究 \\
\hline & 26370248 & 近世仏教説話集の形成·出版 · 享受についての研究－地蔵寺所蔵文献との関わりから \\
\hline & 26370247 & 和刻本漢籍における近世中期の通俗的注釈書の研究 \\
\hline & 26370246 & テキスト面からみた春本研究…戯作者と春本 \\
\hline & 26370245 & 地方青年結社における「文」の実践に関する社会史研究 \\
\hline & 26370244 & 福永武彦、その文学の生成と展開 \\
\hline & 26370243 & ポストコロニアル台湾の日本語作家·黄霊芝に関する総体的研究 \\
\hline & 26370240 & 朝鮮詠の領分——朝鮮俳句とその俳人脈をめぐる総合的研究 \\
\hline & 26370238 & 広島の女性作家·岡田 (永代) 美知代に関する基礎的および総合的研究 \\
\hline & 26370235 & 広津柳浪作品分析を中心とした明治三十年代文学の鳥瞰 \\
\hline & 26370233 & 伊藤永之介の文学がとらえた近代日本農村開発史：発電所建設から八郎潟干拓まで \\
\hline & 26370230 & 森鴎外『椋鳥通信』に見る『スバル』『三田文学』の雑誌間交流に関する研究 \\
\hline & 26370228 & 1930年代日本の経済と地方·農村·満洲の文学における表象に関する研究 \\
\hline & 26370226 & メディア環境との相関性に基づく日本探偵小説の史的研究 \\
\hline & 26370222 & 近代日本児童出版文化史の研究－明治期における博文館出版文化の内容と特質 \\
\hline & 26370216 & 東海地域近世·近代能楽資料の収集·整理とアーカイブ化 \\
\hline & 26284038 & 核·原爆と表象／文学に関する総合的研究 \\
\hline & 14J09614 & 明治期娛楽読物の体系的研究 - - 押川春浪作品の生成と受容の様相を端緒として - - \\
\hline
\end{tabular}




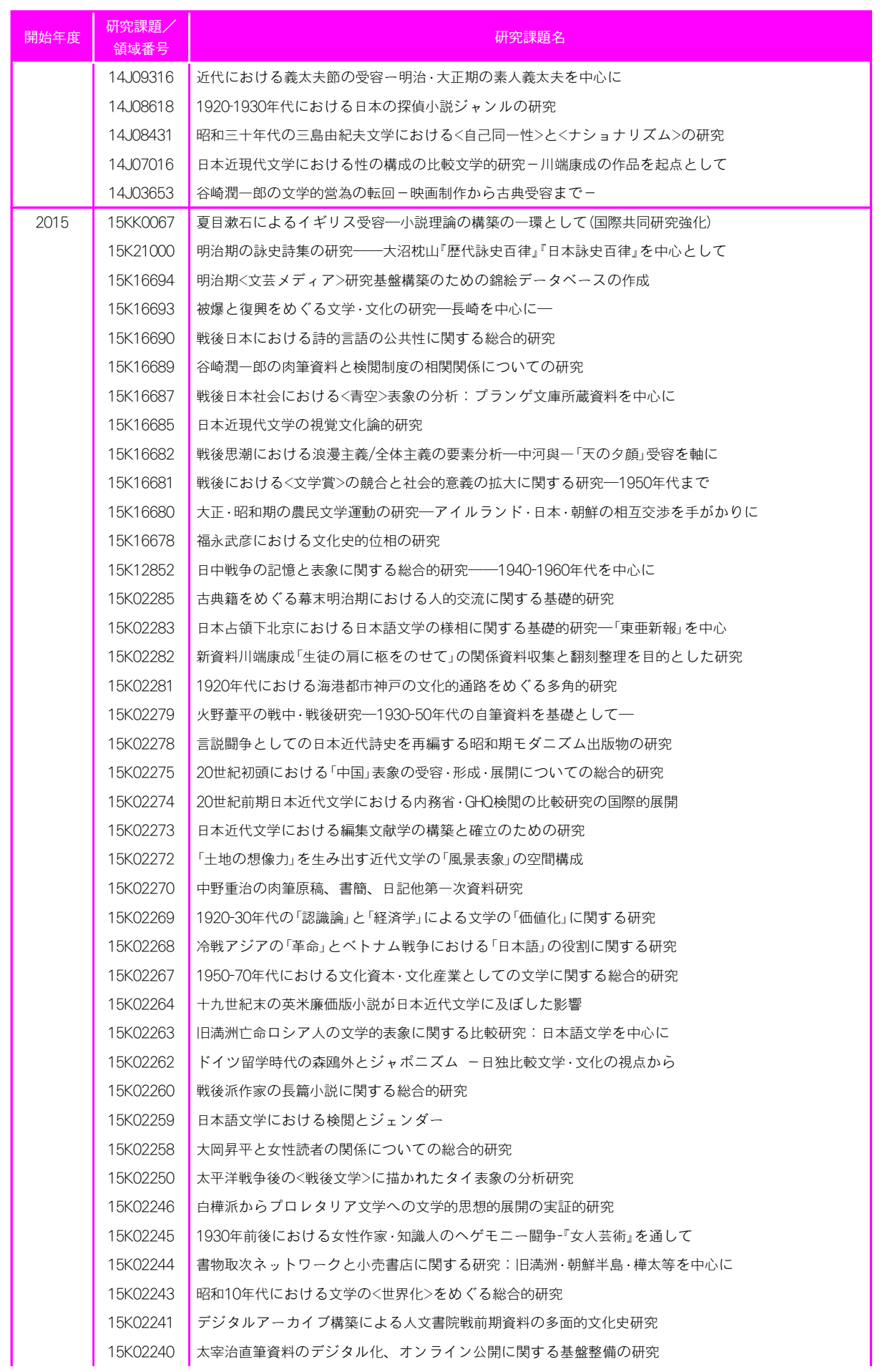




\begin{tabular}{|c|c|c|}
\hline 年度 & $\begin{array}{c}\text { 研究課題／ } \\
\text { 領域番号 }\end{array}$ & 研究課題名 \\
\hline & $\begin{array}{l}15 \mathrm{KO} 2239 \\
15 \mathrm{KO} 2238 \\
15 \mathrm{~K} 02212 \\
15 \mathrm{KO} 2211 \\
15 \mathrm{H} 06845 \\
15 \mathrm{H} 06735 \\
15 \mathrm{H} 06721 \\
15 \mathrm{H} 06630 \\
15 \mathrm{H} 06350 \\
15 \mathrm{H} 06257\end{array}$ & $\begin{array}{l}\text { 方法としての有島武郎－1920年代の朝鮮文壇における女性·子供·労働者の表象 } \\
\text { 戦前期プロレタリア文化運動資料研究 } \\
\text { 近世 近代における風土記研究と郷土意識に関する研究 } \\
\text { 民間の視座を導入した中国通俗文芸受容史の構築一明治以後の民間翻訳をキーワードに一 } \\
\text { アイヌ英雄叙事詩における伝承の流動性に関する研究 } \\
\text { 明治期の極東における和刻本漢籍の流通 } \\
\text { 20世紀前半の渡欧日本知識人達の人的ネットワーク再考 } \\
\text { 森鴎外の歴史叙述の成立過程に関する研究一日独資料による知的ネットワークの可視化 } \\
\text { 文学と美術の交流一小村雪岱の小説挿絵に関する研究一 } \\
\text { 中国の連環画における日本文学の翻訳と再創作 }\end{array}$ \\
\hline 2016 & 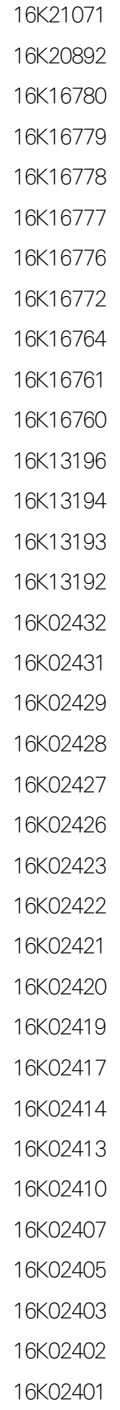 & 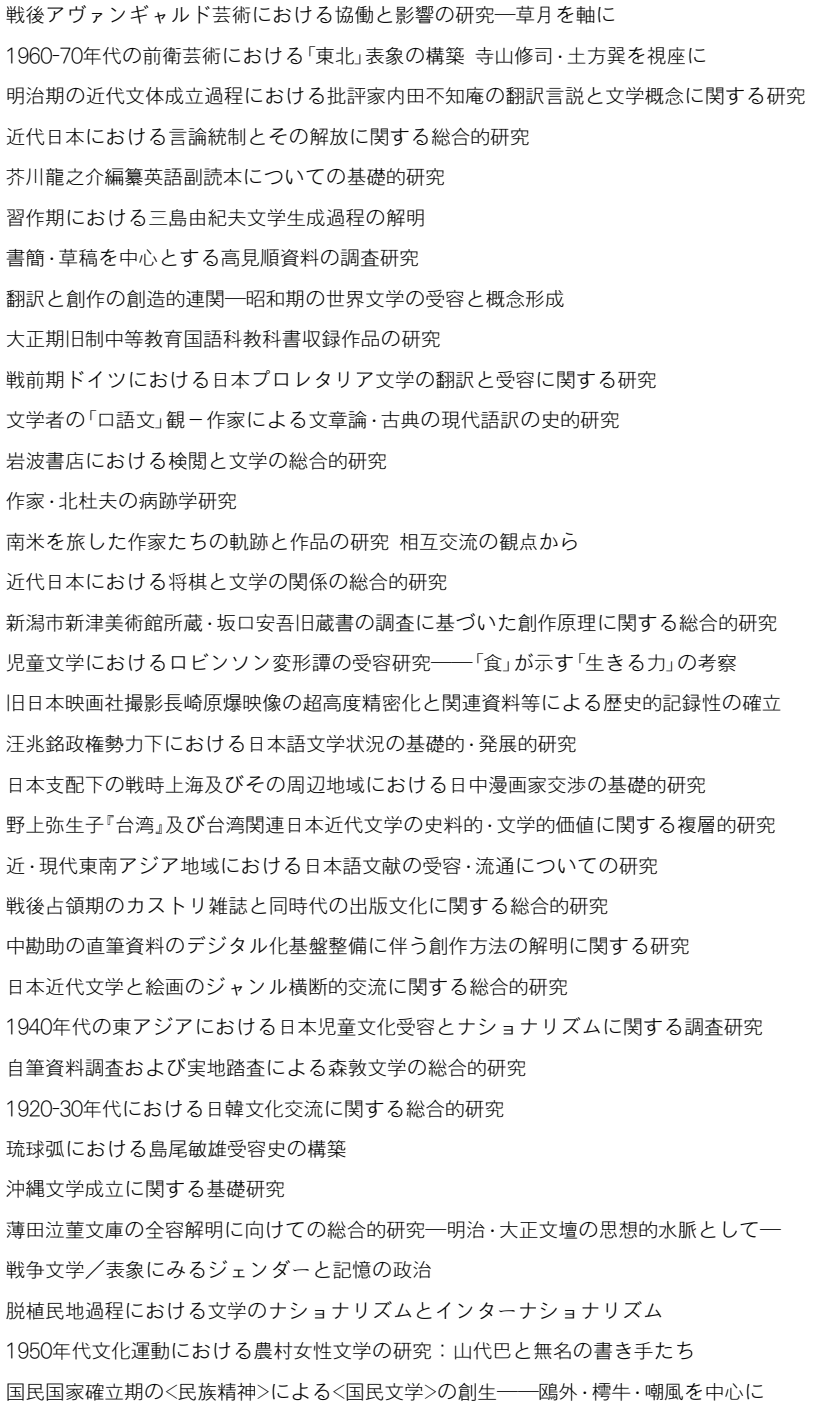 \\
\hline
\end{tabular}




\begin{tabular}{|c|c|c|}
\hline 開始年度 & $\begin{array}{c}\text { 研究課題 / } \\
\text { 領域番号 }\end{array}$ & 研究課題名 \\
\hline & $\begin{array}{c}16 \mathrm{~K} 02400 \\
16 \mathrm{KO} 2398 \\
16 \mathrm{~K} 02397 \\
16 \mathrm{~K} 02396 \\
16 \mathrm{~K} 02395 \\
16 \mathrm{~K} 02385 \\
16 \mathrm{~K} 02372 \\
16 \mathrm{~K} 02366 \\
16 \mathrm{~K} 02365 \\
16 \mathrm{~K} 02360 \\
16 \mathrm{H} 07396 \\
16 \mathrm{H} 07179 \\
16 \mathrm{H} 07112 \\
16 \mathrm{H} 03386\end{array}$ & 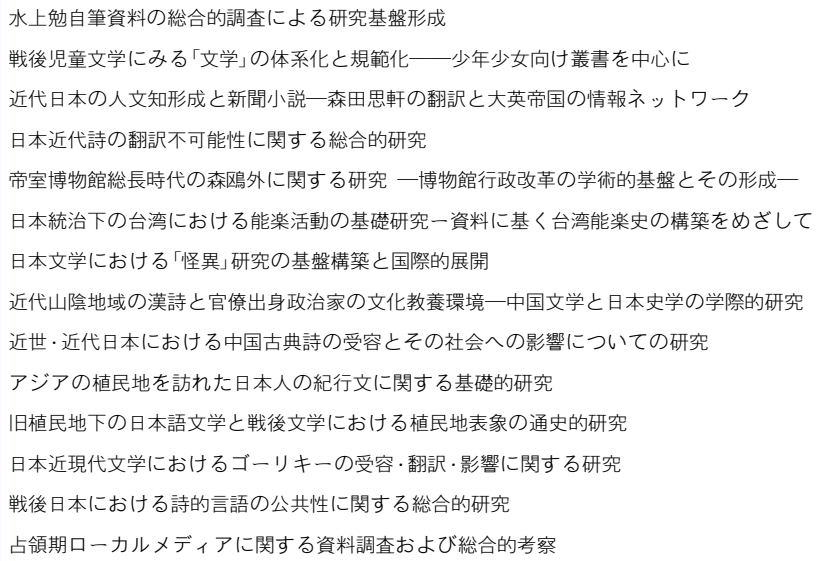 \\
\hline 2017 & $\begin{array}{l}17 \mathrm{~K} 13400 \\
17 \mathrm{~K} 13398 \\
17 \mathrm{~K} 13397 \\
17 \mathrm{~K} 13396 \\
17 \mathrm{~K} 13393 \\
17 \mathrm{~K} 13391 \\
17 \mathrm{~K} 13390 \\
17 \mathrm{~K} 13383 \\
17 \mathrm{~K} 13381 \\
17 \mathrm{~K} 02488 \\
17 \mathrm{~K} 02487 \\
17 \mathrm{~K} 02485 \\
17 \mathrm{~K} 02484 \\
17 \mathrm{~K} 02483 \\
17 \mathrm{~K} 02482 \\
17 \mathrm{~K} 02478 \\
17 \mathrm{~K} 02476 \\
17 \mathrm{~K} 02473 \\
17 \mathrm{~K} 02472 \\
17 \mathrm{~K} 02469 \\
17 \mathrm{~K} 02468 \\
17 \mathrm{~K} 02467 \\
17 \mathrm{~K} 02466 \\
17 \mathrm{~K} 02464 \\
17 \mathrm{~K} 02462 \\
17 \mathrm{~K} 02461 \\
17 \mathrm{~K} 02459 \\
17 \mathrm{~K} 02457 \\
17 \mathrm{~K} 02456 \\
17 \mathrm{~K} 02455 \\
17 \mathrm{~K} 02453\end{array}$ & 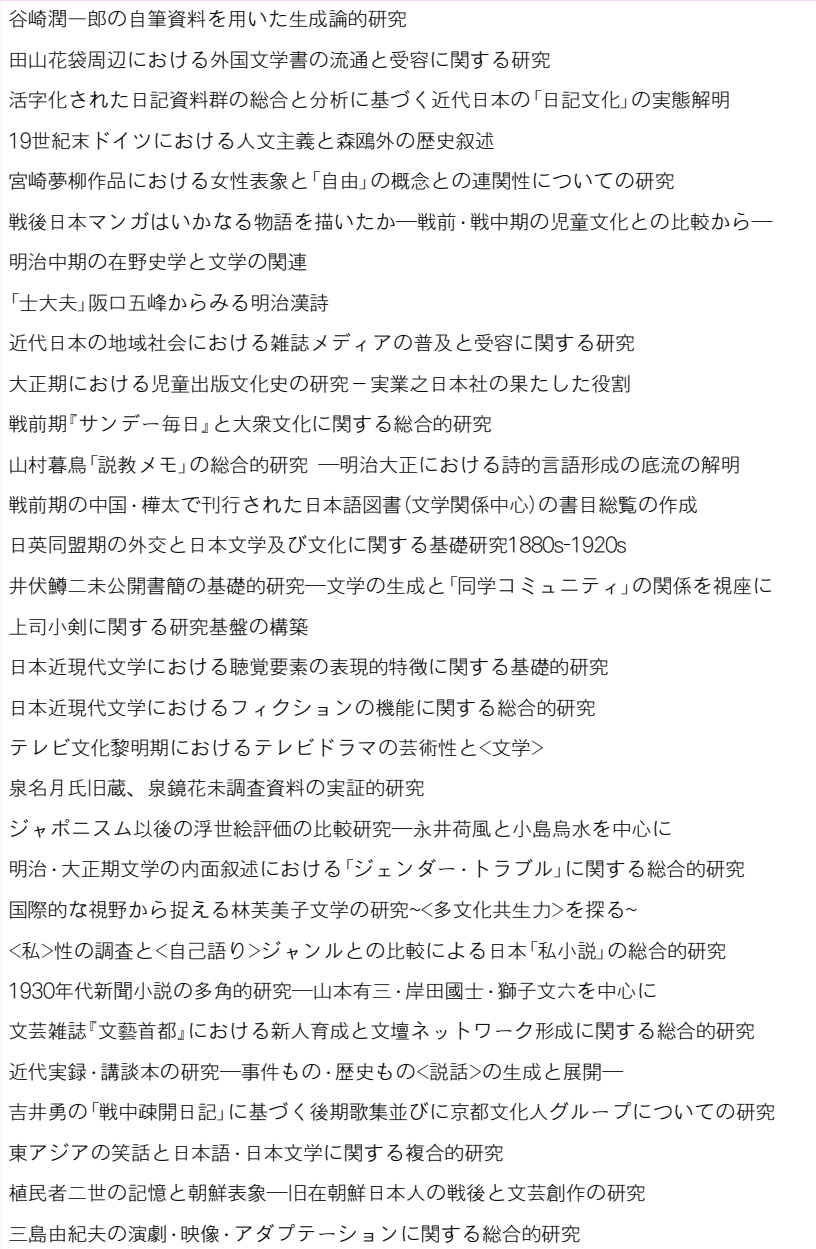 \\
\hline
\end{tabular}




\begin{tabular}{|c|c|c|}
\hline 開始年度 & $\begin{array}{c}\text { 研究課題／ } \\
\text { 領域番号 }\end{array}$ & 研究課題名 \\
\hline & $\begin{array}{l}17 \mathrm{KO} 2452 \\
17 \mathrm{KO} 2451 \\
17 \mathrm{KO} 2450 \\
17 \mathrm{KO} 2449 \\
17 \mathrm{KO} 2448 \\
17 \mathrm{KO} 2433 \\
17 \mathrm{KO} 2432 \\
17 \mathrm{KO} 2431 \\
17 \mathrm{KO} 2430 \\
17 \mathrm{KO} 2414 \\
17 \mathrm{KO} 2413 \\
17 \mathrm{KO} 2410 \\
17 \mathrm{KO} 2408 \\
17 \mathrm{HO} 296 \\
17 \mathrm{HO} 07171 \\
17 \mathrm{HO} 2315\end{array}$ & 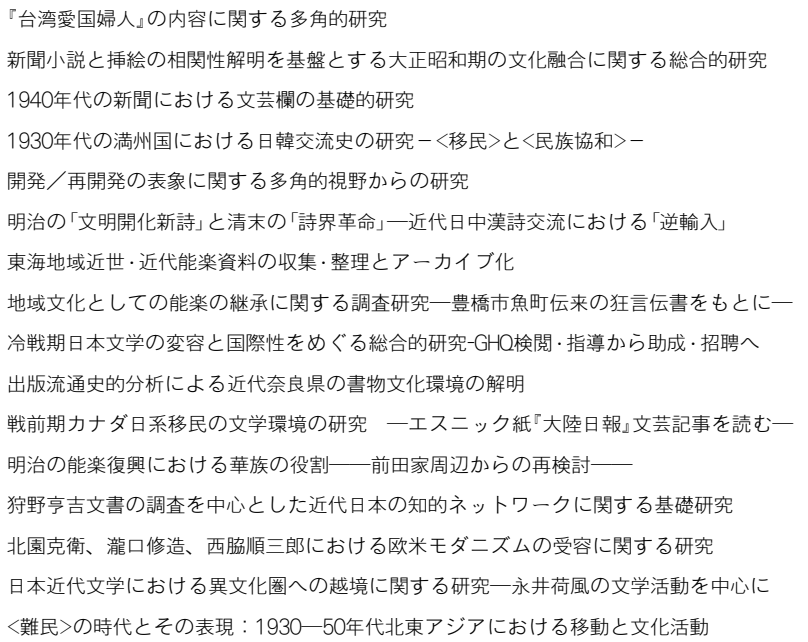 \\
\hline
\end{tabular}

日比嘉高 Yoshitaka HIBI

(日本) 名古屋大学大学院人文学研究科准教授。日本近現代文学·文化研究、移民文学·文化研究、 出版文化研究。『〈自己表象〉の文学史一一自分を書く小説の登場』(翰林書房, 2002)、『ジャパニー ズ・アメリカ移民文学、出版文化、収容所』(新曜社，2014)、『いま、大学で何が起こっているのか』 (ひつじ書房, 2015)、『文学の歴史をどう書き直すのか 二0世紀日本の小説·空間・メディア』 (笠間書院. 2016)、『図書館情調』(編著, 皓星社, 2017)、『連続討議 文系学部解体一大学の未来@ 横浜国立大学』(室井尚編，共著、読書人、2017)、『「ポスト真実」の時代「信じたいウソ」が「事実」 に勝る世界をどう生き抜くか』(津田大介との共著, 祥伝社, 2017) など。 